\title{
Spatial anaphora in Hungarian
}

\author{
György Rákosi, Enikő Tóth \\ Department of English Linguistics, University of Debrecen, Hungary \\ https://doi.org/10.36505/ExLing-2019/10/0043/000405
}

\begin{abstract}
Hungarian employs reflexives in contexts of spatial anaphora to encode a referential dependency with clause-mate antecedents, and pronouns are generally unacceptable in the same configuration. This study shows that pronouns are also an option nevertheless in certain cases for most speakers, the major licensing factor being the distance between the antecedent and the figure located. Our results show that the constraints that govern the distribution of different types of pronominals in spatial anaphora in English are also relevant in Hungarian, albeit to a weaker degree.
\end{abstract}

Key words: anaphora, Hungarian, pronoun, PP, reflexive.

\section{Introduction}

There is considerable variation both within and across languages in terms of the linguistic coding of spatial anaphora: personal pronouns and reflexive anaphors are in competition to establish a referential dependency with the local subject. In English, the default choice is the personal pronoun (1a), and the reflexive is only licensed under special circumstances (1b). These include the availability of antecedents whose point of view is described in the embedding discourse (Reinhart \& Reuland 1993), and the description of locations which are close to the body of the antecedent (see Rooryck \& Vanden Wyngaerd 2011 for an overview). So (1b), unlike (1a) strongly implies that the snake was close to the speaker's body.

In contrast, it is the reflexive which is acceptable across the board in these contexts in Hungarian (2b), and the use of the (pro-dropped) personal pronoun is a very marked option for most speakers, and some of the available linguistic literature simply considers the construction represented by (2a) ungrammatical (see, a.o., É. Kiss 1987: 185-186).

Rákosi (2012), however, reports on a questionnaire study where pronominal anaphora fared relatively well for most speakers in these contexts in first person (average ratings varying between 1 and 0 for individual examples on a 5 pointLikert scale from 2 to -2 ).

Our aim in this paper is to dig deeper into the nature of this variation. We restrict our attention to first person antecedents, as variation with some magnitude is expected only in non-third persons on the basis of the results of Rákosi (2012). We studied two types of PP constructions in a corpus study and a questionnaire study: PPs headed by postpositions that take non-case-marked noun phrase complements, and PPs headed by postpositions which assign a

ExLing 2019: Proceedings of $10^{\text {th }}$ International Conference of Experimental Linguistics, 25-27 September 2019, Lisbon, Portugal 
specific case to their noun phrase complements. We found that the most important factor that facilitates the use of the pronoun in contexts of spatial anaphora is the nature of the space denoted: the pronoun is best (or even better than the reflexive in specific examples) when the space denoted is some distance away from the referent of the pronoun. Thus though the overall distribution of judgements is different, Hungarian does show sensitivity to a factor that is relevant in the case of English spatial anaphora.

(1) a. I saw a snake near me.

b. I saw a snake near myself.

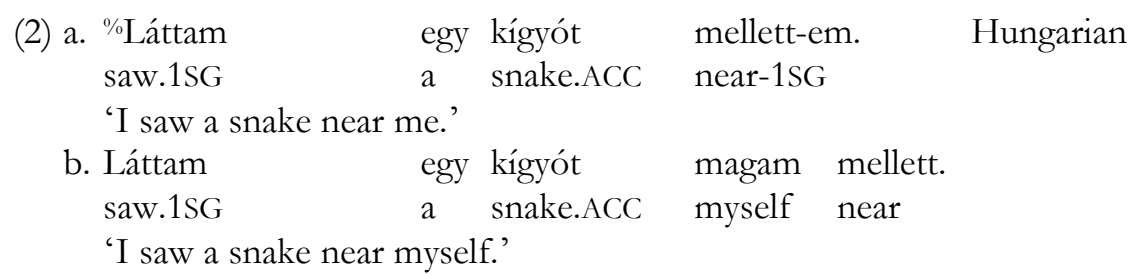

\section{The corpus study and the questionnaire}

To get a better grip on the design of our questionnaire, we conducted a corpus study first. The corpus study was performed on the Hungarian National Corpus (Oravecz et al. 2014), and it consisted of a manual selection of target examples including pronominal PPs with local antecedents in the clause. Such examples are not frequent, but they do occur in the corpus data. The ratio of locally coreferent pronominal PPs and reflexive PPs varies from 1:10 to 1:119 in our sample across the individual $\mathrm{P}$ types, reinforcing our claim that pronominal coding of spatial anaphora is an available option in Hungarian. We used the examples to construct test items for a pilot questionnaire. The aim of the questionnaire study was twofold. First, we wanted to check whether there is individual variation in the judgements concerning pronominal anaphora in Hungarian. It turned out that there is no significant variation, most subjects seemed to show comparable judgement patterns. Second, we wanted to have a baseline of ratings for our follow-up questionnaire.

The main questionnaire contained pairs of sentences, and the items in each pair were identical except for the choice of the PP-complement (pronoun vs reflexive, as in (2) above). Participants evaluated each sentence separately on a 5 -point Likert scale from 1 to 5 . Our underlying intention was to force the subjects to be aware of the competition between pronouns and reflexives. Since pronouns are a marked choice in this domain in Hungarian, if they still receive higher ratings in this specific comparison task, then we have strong evidence that the pronominal coding is a grammatical option. Or it is so under special circumstances: our hypothesis was that pronouns will be acceptable if the location denoted by the PP is not close to the referent of the antecedent (being 
far is taken to be anywhere in the zone which is beyond arm's reach, see Kemmerer 1999 on this). Overall, in a mixed design we had two within-subjects factors with two levels each: pronoun type: pronoun vs. reflexive and location: near vs. far. We also had a between-subjects variable, P-type: one group of participants rated examples with postpositions that do not assign a case on their complements (95 subjects), and the other group saw test items only with postpositions that do (105 subjects).

\section{The results and discussion}

As expected, there was a main effect of pronoun type; in general, reflexives received higher ratings $\left(\mathrm{F}(198,1)=164.56, \mathrm{p}<0.001, \eta^{2}=0.45\right)$. A more interesting finding revealed a significant interaction between pronoun-type and location: $\mathrm{F}(1,198)=531.006, \mathrm{p}<0.001, \eta^{2}=0.73$, which is represented in Figure 1. This indicates that pronouns were slightly preferred when the location is beyond arm's reach of the referent, while reflexives received higher ratings when the location denoted by the PP is within the peripersonal space around the referent of the antecedent. A test item from the questionnaire in (3) below illustrates the pronoun vs. reflexive contrast in the far condition, where szemben 'opposite' is a case assigning postposition.

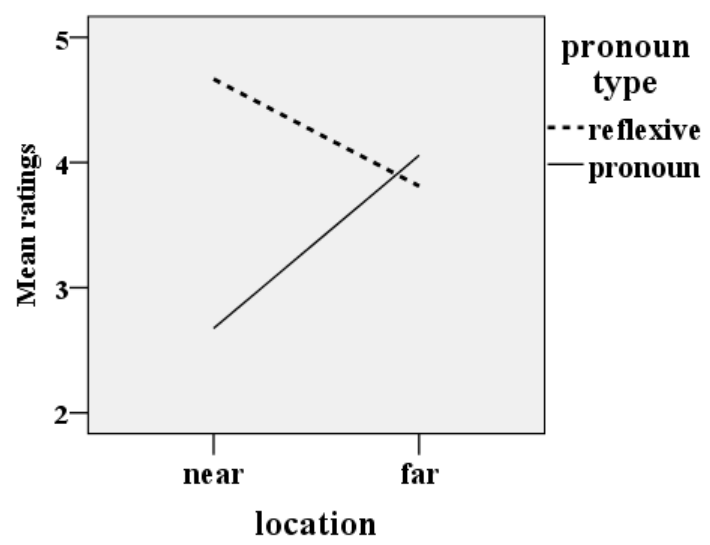

Figure 1. The interaction between pronoun type and location.
(3) a. Köszöntöm itt
vel-em
szemben (...)
közgazdászt.
greet.1SG here
with-1SG
near-1SG
economist.ACC
'I welcome the economist (...) here opposite me.'
b. Köszöntöm itt
szemben $(. .$.
greet.1SG here
myself-with opposite magam-mal
közgazdászt.
'I welcome the economist (...) here opposite me.'
economist.ACC 
(3a) with the pronoun received a mean rating of 4.66 , while $(3 \mathrm{~b})$, where the complement of the $\mathrm{P}$ is a reflexive got an average rating of 2.50 . Hence, our hypothesis that pronouns might become a better option under special circumstances is supported by the results of the questionnaire. Analysing the significant three way interaction $\left(\mathrm{F}(1,198)=37.975 \mathrm{p}<0.001, \eta^{2}=0.16\right)$ shows that pronouns are more acceptable in examples with case-assigning Ps in the far condition than in the near condition. With Ps that do not assign case, pronouns in the far condition do not outperform reflexives, but they do represent a viable alternative since the average ratings are almost the same for pronouns and reflexives in this condition (4.02 and 4.27, respectively).

In sum, pronouns are an option in coding local spatial anaphora in Hungarian, but this option is restricted to non-third persons and to examples where the space denoted is further away from the body of the antecedent. This, to some extent, repeats the English pattern in a more restrictive setting.

\section{Acknowledgements}

The Project no. 111918 (New approaches in the description of the grammar of Hungarian pronominals) has been implemented with the support provided from the National Research, Development and Innovation Fund of Hungary, financed under the $\mathrm{K}$ funding scheme.

\section{References}

É. Kiss, K. 1987. Configurationality in Hungarian. Dordrecht, Reidel.

Kemmerer, D. 1999. "Near" and "far" in language perception. Cognition 73, 35-63.

Oravecz, Cs., Váradi, T., Sass, B. 2014. The Hungarian Gigaword Corpus. In: Proceedings of LREC 2014.

Rákosi, Gy. 2012. A magyar birtokosszerkezetű viszonyjelölőkről, avagy kígyók szájfénnyel és esernyővel. [On possessive adpositional constructions in Hungarian, or snakes with lip glosses and umbrellas.] In É. Kiss, K., Hegedűs, A. (eds.) 2012, Nyelvelmélet és dialektológia, 154-173. Piliscsaba, PPKE BTK.

Reinhart, T., Reuland, E. 1993. Reflexivity. Linguistic Inquiry 24 (4), 657-720.

Rooryck, J., Vanden Wyngaerd, G. 2011. Dissolving binding theory. Oxford University Press. 